Abstracta Iranica Abstracta Iranica

Revue bibliographique pour le domaine irano-aryen

Volume 40-41 | 2019

Comptes rendus des publications de 2017-2018

\title{
Dieter Weber. "Accountancy of a Zoroastrian Craftsman in Early Islamic Times (662-664 C.E.)"
}

Samra Azarnouche

\section{(2) OpenEdition}

1 Journals

\section{Édition électronique}

URL : http://journals.openedition.org/abstractairanica/50283

DOI : 10.4000/abstractairanica.50283

ISBN : 1961-960X

ISSN : 1961-960X

Éditeur :

CNRS (UMR 7528 Mondes iraniens et indiens), Éditions de l'IFRI

Référence électronique

Samra Azarnouche, «Dieter Weber. "Accountancy of a Zoroastrian Craftsman in Early Islamic Times (662-664 C.E.)" », Abstracta Iranica [En ligne], Volume 40-41 | 2019, document 68, mis en ligne le 30 décembre 2019, consulté le 21 avril 2021. URL : http://journals.openedition.org/abstractairanica/ 50283 ; DOI : https://doi.org/10.4000/abstractairanica.50283

Ce document a été généré automatiquement le 21 avril 2021.

Tous droits réservés 


\title{
Dieter Weber. "Accountancy of a Zoroastrian Craftsman in Early Islamic Times (662-664 C.E.)"
}

\author{
Samra Azarnouche
}

\section{RÉFÉRENCE}

Dieter Weber. “Accountancy of a Zoroastrian Craftsman in Early Islamic Times (662-664 C.E.)", Bulletin of the Asia Institute, vol. 27 (2013), 2017, p. 129-141

1 Déchiffrement et analyse d'un document inédit, le parchemin $n^{\circ} 231$ de la «Pahlavi Archive " préservée à la Bancroft Library de Berkeley, qui liste les revenus et dépenses d'un menuisier (durgar) nommé Zādōy, au service d'un entrepreneur nommé WindādBurzmihr, dans un registre visiblement destiné à la levée de l'impôt. La première partie de ce document « officiel » (nāmag ī nēk) contient les revenus de Zādōy sur deux années et la seconde partie donne les sommes investies par celui-ci en partenariat avec d'autres personnes.

2 Des termes se rapportant à la production agricole (šan, tige de chanvre), ou aux pratiques financières (ādānīh adēn: entrée des biens; gōhrīgēnišnīh : indemnités) sont commentés par l'A. qui explicite aussi dans ses commentaires les lectures assurées et celles pour lesquelles des alternatives peuvent être proposées. La fonction encore mal définie du hammōzag (" Proctor ») est également attestée dans ce document. 


\section{AUTEURS}

\section{SAMRA AZARNOUCHE}

EPHE, Mondes iranien et indien, Paris 